\title{
Influence of Victims' Parents in Diversion Process to the Diversion Effectiveness as an Effort of Juvenile Crimes Settlement
}

\author{
AM.Endah Sri Astuti ${ }^{1}$,RahmiDwiSutanti ${ }^{1}$ \\ \{endsriastuti@yahoo.com ${ }^{1}$, rahmidwisutanti@live.undip.ac.id ${ }^{2}$ \} \\ ${ }^{1,2}$ Diponegoro University, Jl. Prof. H. Soedarto, S.H. Tembalang, Tembalang, Kota Semarang, Jawa \\ Tengah 50275 Indonesia
}

\begin{abstract}
In Indonesia, a diversion has become one of the ways to solve child crime through UU.No.11 / 2012 on Child Criminal Justice System. Diversion aims to provide recovery against damage caused by crimes committed by children. The diversion will be realized if there is an agreement between the perpetrator and the victim, especially the community, and other parties appointed by law. Given the immature personal condition of the child, both physic and psychic, then in the process of diversion, both children (victim and the perpetrator) require parental assistance in giving the agreement. The purpose of this study was to determine the influence of victim's parents in a diversion process to the effectiveness of diversion in settlement of child crime. To answer this problem, the method used a qualitative research method. The result of this study shows that the victim's parents give enough influence to the child in giving agreement in the process of diversion. From this study, it can be concluded that the diversion is useful concerning specific criminal acts which consequently can be tolerated by the victim, and it does not attack the honor and dignity of the victim.
\end{abstract}

Keywords: Diversion, Juvenile Crimes, Penal Settlement

\section{Introduction}

Removed from established support systems, children and adolescents confined to such placements often face harsh conditions that can result in negative consequences long after discharge (e.g., Dmitrieva, Monahan, Cauffman, \& Steinberg, 2012; Lambie \& Randell, 2013; Mendel, 2011). So, the improvement of quality or quantity of conflicted children under the law needs the specific policy to protect their future to become mature individuals physically, spiritually, and intellectually. This policy needs to avoid children from the negative effect of imprisonment. To make it real, the Indonesian Government develops this policy in the form of "Diversion" that uses a Restorative Justice" approach. Restorative justice programs emerged in the 1970s, offering alternative methods for dealing with crime (Elliott \& Gordon, 2005; McGarrell, 2001). Restorative Justice is also a primary response to calls from victim advocates for alternative approaches that expand victims' rights injustice processes and promote outcomes that address needs of victims, offenders, and communities[1][2][3][4].

Through article 7 clause 1 Act No. 11 the Year 2012 Regarding Juvenile court justice system, the government emphasizes the attempt of diversion to the investigation, prosecution, or trial process of juvenile cases. This policy is taken in order to avoid children from the Criminal Justice System intervention as limited as possible. A statement of 
Johnstone\& Van Ness supports this idea that Restorative Justice is an open concept where no single meaning is found, hence the formulation and policy development are more dynamic following the context of its needs.[1]

Beside deeming individual violations as mistakes and demanding the healing to every damage caused from criminal act conducted by children, diversion suitability for children to settle their cases out of court can be done by preventing children from seizing their freedom and inserting responsibility to children (Article 6). Specifically, studies of restorative justice indicate that its programs provide more opportunities for crime victims to have their voices heard, receiving answers to participate in a process where they interact with the offender and that they may feel pressured to participate.[5][6][2]

Cournarelos and Weatherburn noted that if the court did nothing, most first time young offenders would not get into any further trouble.[7] Ironically, the new way ordered to avoid children from Criminal justice system is not as easy as one hopes. The number of diversions is lower than the verdicts judged by the court. Many causes cause the lower number. One of the assumptions is a lower number of victim's parent complicity in an agreement process between victim and offender. The process of diversion is not easy since diversion needs the agreement between the victim, offender, and the society as well as the other related parties chosen by the law, even if it upholds positive values for solving children's cases. Opposite to Laurence Miller opinion which stated that the restorative procedure was personalized, transparent, and comprehensive, and hence offered relief from the formality that is dominant in the judicial proceedings. It made the victim feel at ease.[8]

According to Woolford and Ratner restorative interventions have been implemented worldwide and are being applied concerning a range of crimes, including property and violent crime, committed by a juvenile or adult offender against an individual victim or a group.[9]According to Jeffrey D. Burke et al., parental involvement is now widely recognized as a crucial consideration for promoting positive chillout comes in education, mental health, child welfare, and juvenile justice.[10]The immaturity of children physically or psychologically encourages the policymaker to involve parents'/children guardians' supervision and assistance in the diversion process, whether for the victim or the offender.

Thus, diversion can be executed if these related parties of some instances agree that the settlement of criminal activity can be solved by diversion, mainly the victim. In other words, although restorative justice claims that it is "victim-centered," and deliberately focused on healing harms to victims, some studies report that particular applications of restorative justice may not be entirely consistent with fundamental principles and values. The agreement between victims is inseparable from the process of dialogue parents and children since children are still under the control of the parents. Besides, parents are the agent of value and agent of control of children's actions in their life. It is in line with Bazemore\&Umbreitopinion that thebalanced and restorativejusticeapproach, adopted by many juvenilesystems, recognizes parental involvement as a critical component to intervention efforts.[11]

This research aims to unveil the diversion implementation in Indonesia and to unveil victim's parent influence in the diversion process to the diversion effectiveness to settle juvenile crimes.

\section{Methodology}

To know parents' roles in diversion process, this research used the qualitative method with purposive sampling to get the real pictures of diversion process besides relying on 
supporting data for the mechanism of diversion in juvenile crimes settlement. In line with Vicki Lawal et al. opinion, qualitative methods were used in addressing contextual issues in the study which enabled the researcher to provide a detailed description and explanation of the processes of the local context is explored.[7]The samples used in this research were parties involved in the diversion process, which are parents and children (from victims' or offenders' side). Balasore Correctional Facility, as one of the laws enforcing components, gave "Social Inquiry" data and assistance to conflicted children in every Criminal justice system process for the investigator, prosecuting attorneys, and the judges. The location of this research was in the karesidenanor ex-residency, which is concentrated on the area of Correctional Facilities in Central Java.

\section{Findings}

\subsection{Implementation of Diversion Process in Indonesia}

Diversion is a new policy with specific nature taken by Indonesia's Government through Act Number 11 the year 2012 regarding Juvenile court justice system. This policy is used to guarantee and give children's rights on their behalf, especially for those who are conflicted by the law. Using a restorative justice approach, Howard Zehr defines diversion as one of the ways to solve a conflict aimed to heal the damage caused by criminal acts[12][13].

According to the Act for children conflict in the law, diversion is defined as "The redirection of Children's cases from the court's trial system to out of court. Not many children with legal conflict cases settled by diversion even if the law obligated the settlement of their cases by diversion. In other words, juvenile cases are solved under the adjudication of the court. This is in line with Whitaker, Severy, \& Morton state that treating youth in the community diversion is seen as a way to reduce further involvement with the juvenile justice system. The idea has been particularly intriguing because of its added benefit of relieving an overburdened judicial system. [14]

The data of children-in-law conflict in Bapas in six Districts in Central Java law:

Table 1. Description About Children Conflict in Law (6 Districts in Central Java)

\begin{tabular}{|r|l|c|c|c|c|}
\hline $\begin{array}{l}\text { No } \\
\text { Areas }\end{array}$ & $\begin{array}{c}\text { Children Have } \\
\text { Legal } \\
\text { ConflictAmoun } \\
\text { t }\end{array}$ & $\begin{array}{c}\text { State } \\
\text { Court } \\
\text { Decision } \\
\text { S }\end{array}$ & Diversion & $\begin{array}{c}\text { Percenta } \\
\text { ge }\end{array}$ \\
\hline 1 & $\begin{array}{l}\text { BAPASCLASS 1 } \\
\text { SEMARANG }\end{array}$ & 139 & 87 & 52 & $37.40 \%$ \\
\hline 2 & $\begin{array}{l}\text { BAPASCLASS II } \\
\text { MAGELANG }\end{array}$ & 119 & 76 & 43 & $36.1 \%$ \\
\hline 3 & $\begin{array}{l}\text { BAPASCLASS II } \\
\text { PATI }\end{array}$ & 78 & 37 & 41 & $52.6 \%$ \\
\hline 4 & $\begin{array}{l}\text { BAPASCLASS II } \\
\text { PEKALONGAN }\end{array}$ & 189 & 106 & 83 & $43.9 \%$ \\
\hline 5 & $\begin{array}{l}\text { BAPASCLASS II } \\
\text { PURWOKERTO }\end{array}$ & 326 & 191 & 135 & $11.84 \%$ \\
\hline 6 & BAPASCLASS II & 289 & 166 & 134 & $11.75 \%$ \\
\hline
\end{tabular}




\begin{tabular}{|r|r|r|r|r|l|}
\hline & SURAKARTA & & & \\
\hline$\gamma_{1}$ & TOTA & 1140 & 663 & 488 & \\
\hline
\end{tabular}

The number of Children in Law Conflict is those who are twelve to eighteen years old and suspected of committing a criminal act. Therefore, the number of Children in Law Conflict who get the court decision and the diversion is not necessarily the same as the total number of Children in Law Conflict as by Article 69 Clause 2 Act. Number 11 of 2012, children in conflict under the age of fourteen can only be subject to action. In other words, they cannot be subject to criminal charges.

Based on the data, out of 1140 cases, 488 cases were successfully settled with diversion, while 652 cases were settled in court without diversion in the region of Bapas Central Java. From that figure, it can be concluded that the children's law conflicts have more criminal justice process even though the law requires settlement of cases by diversion at each stage of completion. Daly (2006) notes that the actual practice may never fully realize the idealized vision of restorative justice, but more importantly, such negative experiences are often preventable when those practices closely approximate the theory.

The research found that one of the most critical gaps appears rooted in an assumption about process and meaning of diversion by victims and offenders. Both of them neither fully understand the meaning and focus of the diversion process, nor have reasonable expectations about what would happen and how to adequately express themselves during the processes. Another reason for victims having occasional restorative conferencing experiences that are less than wholly positive with youthful offenders may be the lack of moral maturity and lower capability for empathy among youthful offenders. This was often exemplified by their difficulty in recognizing victims' troubles during conferencing sessions. The offenders seemed to participate in the diversion process for personal reasons to straighten out their reputation rather than to repair harms to their victims. The consequences of this, some victims viewed their offenders would change. On the contrary, sometimes the offender is in an incapable condition to give high restitution that has been determined by a victim or victim's family. This situation can make the offender refuse the meaning of diversion purpose.

Meanwhile, law for children in Indonesia determines that a criminal offense committed by a child can be attempted with a diversion if qualified. Article 7 (2) of Constitution No.11 of 2012 requires that a case or criminal act can be pursued with diversion way if the criminal act is:

a. threatened with imprisonment under 7 (seven) years; and, b. It is not a repeated crime.

In addition, one must notice that diversion can be done if the age of the children should be \pm 14 which is presumed to conduct crimes with a punishment of \pm 7 years of conviction in Article 32 Clause 2, because in the cases where children aged 12 (twelve) years old have been allegedly conducting crimes, the investigator, social counselor, and professional social worker can decide to:

a.return the children to their parents/guardian; or

b.opts them in pedagogical guiding and advisory in government's institution or LPKS or Social Welfare Institution whether in the central or in the local area not more than 6 (six) months. (It should be emphasized again that what it means by conflicted children in this law is children aged from 12 to 18 which is suspected of conducting crimes).

Another fact found in the research is that the victims did not want to settle the problem by diversion because the victims want the crime to resolve in court only. Such matters 
should not be enforced for various reasons since the agreement given by the victim primarily must reflect a form of forgiveness of a criminal offense perpetrated by the offender, rather than merely avoiding a criminal offender from interfering in the criminal justice system, especially if the criminal acts that occurred attack the honor of the victims and make them suffer. This reasoning can be seen from the data in this study (three districts of Bapas in central Java) that cases of sexual assault or murder or other cases with high risks (thievery) are unsuccessfully attempted to diversion.

Table 2. Description About diversion experience from three Districts of Bapas in CentralJava

\begin{tabular}{|c|c|c|c|c|c|}
\hline \multirow[t]{2}{*}{ No } & \multirow[t]{2}{*}{ Violation/Crime } & \multirow{2}{*}{$\begin{array}{l}\text { Amount/a } \\
\text { rea } \\
\text { Smg/Srk/ } \\
\text { Pkl/ }\end{array}$} & \multicolumn{3}{|c|}{$\begin{array}{l}\text { DIVERSION } \\
\text { Smg/Srk/Pkl/ }\end{array}$} \\
\hline & & & $\begin{array}{l}\text { Successf } \\
\text { ul }\end{array}$ & failure & $\begin{array}{l}\text { In } \\
\text { process }\end{array}$ \\
\hline 1 & Child violence & $10 /-/-/$ & $6 / / /$ & $4 / / /$ & $-/ / /$ \\
\hline 2 & Thievery & $42 / 81 / 27 /$ & $11 / 35 / 1$ & $\begin{array}{lll}31 / 24 / 0 \\
/\end{array}$ & $0 / 22 / 0 /$ \\
\hline 3 & Attacking & $23 /-/ 4 /$ & $5 /-/ / /$ & $18 /-/ /$ & $0 /-/ /$ \\
\hline 4 & Narcotic & $5 / 6 / 5 / /$ & $0 / 1 / 0 / /$ & $5 / 2 / 0 /$ & $0 / 3 / 0 / /$ \\
\hline 5 & Gambling & $1 / 3 / 2 / / /$ & $0 / 3 / 0 / /$ & $1 / / 0 /$ & $0 / / 0 / /$ \\
\hline 6 & Drug dealing & $6 /-/-1$ & $0 / /-/ / /$ & $1 /-/$ & $5 / /-/ / /$ \\
\hline 7 & Psychotropics & $1 /-/-/$ & $0 /-/-/$ & $1 /-/-/ / /$ & $0 /-/-/$ \\
\hline 8 & Battering & $5 / 35 /-/$ & $5 / 24 /$ & $0 / 3 / / /$ & $0 / / 8 /-/$ \\
\hline 9 & $\begin{array}{l}\begin{array}{l}\text { Possession of stolen } \\
\text { goods }\end{array} \\
\end{array}$ & $1 /-/-/$ & $0 /-/-1$ & $1 /-/ / /$ & $0 / /-/$ \\
\hline 10 & Traffic Accidents & $7 / 10 / 1 /$ & $7 / 7 / 0 /$ & $0 / 0 / 0 / /$ & $0 / / 3 / 1$ \\
\hline 11 & Bringing a sharp weapon & $-13 /-1$ & $-12 /-1$ & $-10 /-/ /$ & $-/ / 1 /-/$ \\
\hline 12 & Kidnapping & $-/ 2 /-/-1$ & $-/ 1 / / /$ & $-/ 0 / / /$ & $-/ / 1 / /-$ \\
\hline 13 & Goods Vandalism & $-/ 14 /-/-/$ & $-/ 11 /$ & $-/ 3 / / /$ & $-/ / 0 /-1$ \\
\hline 14 & Deception & $-12 /-1-1$ & $-/ 1 / / /$ & $-/ / 0 / /$ & $-/ / 1 /-/$ \\
\hline 15 & Extortions & $-/ 1 / 2 /-/$ & $-/ 0 / 0 / /$ & $-/ / 1 / 2 / /$ & $-/ / 0 /-/$ \\
\hline 16 & Terrorism & $-/ 1 /-/$ & $-/ 0 /-/ /$ & $-/ / 0 / / /$ & $-/ / 1 /-/$ \\
\hline 17 & Pornography & $-/ 1 /-/$ & $-/ 0 /-/ /$ & $-/ 1 / /$ & $-/ 0 /-/$ \\
\hline 18 & Abandonment & $-/ 1 /-/$ & $-/ 1 /-/ /$ & $-/ 0 / / /$ & $-/ 0 /-1$ \\
\hline 19 & Copulation & $10 / 33 /-$ & $0 / 1 /-/ /$ & $10 / / 24 / /$ & $0 / / 8 /-/ /$ \\
\hline 20 & $\begin{array}{l}\text { Violation of the health } \\
\text { law }\end{array}$ & $-/ / 1 / /$ & 0 & 0 & 0 \\
\hline 21 & $\begin{array}{l}\text { Children protection } \\
\text { category (specific in } \\
\text { Pekalongan)maybe about } \\
\text { sexual crime in child } \\
\text { (Act. 35 Th.2014) }\end{array}$ & 17 & 0 & 0 & 0 \\
\hline 22 & Others & 1 & 0 & 0 & 0 \\
\hline
\end{tabular}

However, on the contrary for the cases that are in the mild category and even the case of the victim as well as the offender, get the opportunities for diversion, such as narcotics 
crime and gambling. It was done in the best interests of the child. Narcotics offenders who are still in the category of users need treatment which involves medical and social rehabilitation rather than punishment of the state authorities.

Based on the explanation of the implementation of diversionary effort, it can be concluded that:

1. The children's cases in conflict with the law are not eligible for diversion.

2. The difficulty to unite the victim and the offender

3. Less understanding of the purpose of diversion, especially from both the victim and the offender.

4. The victim insisted very high restoration that could not be paid by the offender.

5. The difficulty in the mediation process was still there since both parents from the offender and the victim prioritize arguments which are only based on their interests.

The existence of the number of obstacle 2 to 5 is average since victims had to carry on much harm, whether physically, psychologically, or materially. Thus, a diversion will only be reached by making deals with the victims. (This fact can be seen from the number of diversions done by three areas of Correctional Facilities in Central Java).

\subsection{Victims Parent's Influence in Diversion Process}

The difficulty of agreement in the diversion process motivated the Policymaker to make efforts for diversion on every step of justice, that is from the investigation, prosecution, and inspection. In its application, there should be an agreement from the victim in the mediation. Thus, the victim is the primary key to diversion to settle the crimes. The result of this research shows that the seriousness of crime influences a victim and his or her parent to give agreement in the diversion process.

Since children have unstable maturity, with its limit to everything, children will be assisted by their parents or their guardians (from victims' or offenders' side). It is also because children do not understand the harmony between interest, justice, and future hopes. They will learn them in the process of mediation.

Parents have important roles in solving the conflict that they should protect their children. The wrong side of assistance is related to conflicts with harms or injuries which triggers' parents' subjectivity from both conflicting sides, especially the victims'. This subjectivity is rational since the familial relationship between parents and children will complicate the mediation in the diversion by debating on their behalf. From the findings, these argumentations became the obstacles of diversion. In the end, parents indirectly take the role of the child in giving his deal in the process of diversion. The dominance of parents is not only an instinct solely to protect their children, but the parental character which is then also reflected in the way parents take care of their children, which is also a factor influencing the role.

The role of parents in assisting their children cannot be ignored because of the condition of the victim, where the child experiences various traumas, both physics and psychics, which will affect the condition of the child. Similarly, child offenders, on the other hand, are careless and causing harm to others. Not all offenders deliberately plan their actions, but the carelessness of his immaturity causes the offender to be responsible for his actions. Therefore, each side of one person is a victim. On the other hand, the parent wants their child to be forgiven.

This research showed fact (from parents' influence) that the agreement of diversion is also related to the type of crimes done by the offenders along with the level of harms experienced by the victims. 
The data from two units of CF show the violation along with its level of diversion. From the data, it can be concluded that criminal acts are severe violations of the moral values of community life, and diversion does not happen often. As an example of a criminal act of intercourse in the Bapas Region of Semarang, out of 10 cases, none was successful, while 33 cases of intercourse in the Bapas Region of Surakarta were only one who succeeded in diversion, 24 failed, 8 cases still in process. Then from 23 cases of beatings in the Semarang Bapas Area, only 5 cases were successfully resolved by diversion. Theft with various levels of violations and consequences of this crime, from 81 cases, only 35 cases succeeded in implementing the diversion mechanism and 24 remaining failures were still in process. This is very different from a Traffic Accident case. Out of 7 cases, all can be solved through diversion. Besides, the type of crime gives effect to the negation of diversionary action. Interviews with some parents and Bapas's officer also show that the willingness of the offender to provide compensation also affects the success or failure of the diversion deal.

On the one hand, things like this may be and can be regarded as fairness, though their nature is very subjective and may even be exaggerated. However, the victim of a particular type of offense requires a physical recovery, not to mention a recovery that requires a tremendous financial need. This kind of damage should be an awareness of the perpetrator.

The interview with parents showed that the availability of the offender to pay back the costs also influenced the diversion. It can be seen as a regular thing, even if the number was subjective or even excessive. Somehow, it should not be forgotten that victims of certain crimes need physical healing which possibly needs enormous funds. These harms should have raised awareness from the offenders. Howard Zehr also strengthens that most victims experience intense feelings of anger: at the person who did this, at others who should have prevented it, at God who allowed or even caused it. This intense anger may contradict the values they profess, increasing their guilt.[12] Related to this problem, Zehr also said that crime, like cancer, upsets this sense of order and meaning.

Consequently, crime victims, like cancer victims, want answers. Why did this happen? What could have I done to prevent it? These are only a few of the questions which nag at victims. Answers to such questions are relevant because the answers restore order and meaning. If we can provide answers to the questions of what and why the world can make sense again. Without answers, victims tend to blame themselves, others, and God.

\section{Conclusion}

Based on the facts found in this study, it can be concluded that although the number of diversions achieved by law enforcers in settlement of child crime is small compared to the judgment of judges imposed by the judge in the criminal offense, there appears to be an empirical reason for bringing about justice in order for restorative justice can "work" in restoring victims, offenders, and communities, when restorative practice helps bring peace. What should be maintained concerning diversion is that restorative justice works as a strengthening of democracy; and giving justice, dignity, and also healing for the victim. It shows a crime reduction strategy. Overall, it can be argued that the implementation of the diversion in the research area has been attempted as much as possible in accordance with the law and the best interest of the children even if it does not achieve the maximum expectation because there are obstacles that arise in the process of diversion which cannot and should not be imposed, i.e., the victim's rights to accept the deal or not.

Parents as a child's companion in a family have enough influence on their children because parents act as the "agent of control" and "agent of value" in the child's life. It is 
related to the decision to accept or reject the agreement in the process of diversion. A child will listen to the views and considerations of their parents. The seriousness of the criminal act and the victim's damage will further minimize opportunities for perpetrators to gain diversion. Indirectly the role of parents in this case also affects the working mechanism of diversion as a way of settling criminal acts. In the present conditions diversion with all its difficulties is quite useful as a way to settle a child crime in specific cases, because the process of diversion is indeed a process that works through a deal democratically and not an arena of coercive interests to settle a crime.

\section{References}

[1] D. W. Van Ness and K. H. Strong, Restoring Justice: An Introduction to Restorative Justice: Fifth Edition. 2014.

[2] J. J. Choi, G. Bazemore, and M. J. Gilbert, "Review of research on victims' experiences in restorative justice: Implications for youth justice," Child. Youth Serv. Rev., 2012.

[3] J. Dmitrieva, K. C. Monahan, E. Cauffman, and L. Steinberg, "Arrested development: The effects of incarceration on the development of psychosocial maturity," Dev. Psychopathol., 2012.

[4] I. Lambie and I. Randell, "The impact of incarceration on juvenile offenders," Clinical Psychology Review. 2013.

[5] S. G. Bazemore, M. S. Umbreit, and United States. Office of Juvenile Justice and Delinquency Prevention., Balanced and restorative justice: program summary. 1994.

[6] K. Daly, "The Limits of Restorative Justice," in Handbook of Restorative Justice: A Global Perspective, 2006.

[7] V. Lawal, C. Stilwell, R. Kuhn, and P. G. Underwood, "Information literacy-related practices in the legal workplace: The applicability of Kuhlthau's model to the legal profession," J. Librariansh. Inf. Sci., 2014.

[8] L. Miller, "Juvenile crime and juvenile justice: Patterns, models, and implications for clinical and legal practice," Aggression and Violent Behavior. 2014.

[9] A. Woolford and R. S. Ratner, "Disrupting the informal-formal justice complex: On the transformative potential of civil mediation, restorative justice and reparations politics," Contemp. Justice Rev. Issues Crim. Soc. Restor. Justice, 2010.

[10] C. Coumarelos and D. Weatherburn, "Targeting Intervention Strategies to Reduce Juvenile Recidivism,” Aust. N. Z. J. Criminol., 1995.

[11] J. D. Burke, E. P. Mulvey, C. A. Schubert, and S. R. Garbin, "The challenge and opportunity of parental involvement in juvenile justice services," Children and Youth Services Review. 2014.

[12] H. Zehr, Changing Lenses, 3rd ed. Scottrade: Herald Press, 2005.

[13] M. Zennova, Restorative Justice: Ideals and Realities. Burlington: Ashgate, 2007.

[14] J. M. Whitaker, L. J. Severy, and D. S. Morton, "A comprehensive communitybased youth diversion program.," Child Welfare, 1984. 